\title{
ANIZOTROPIE MAGNETICKÉ SUSCEPTIBILITY HORNIN NA KONTAKTU METABAZITOVÉ A DIORITOVÉ ZÓNY BRNĚNSKÉHO MASIVU V OKOLÍ VELKÉ BABY U JINAČOVIC
}

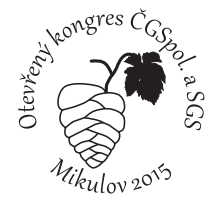

\author{
Anisotropy of magnetic susceptibility along the contact between the Metabasite \\ and Diorite zones of the Brno Massif in the Velká Baba area near Jinačovice
}

\author{
Lukáš Mareček, Rostislav Melichar \\ Ústav geologických věd, Prírodovědecká fakulta Masarykovy univerzity, Kotlářská 267/2, 61137 Brno; \\ e-mail:marecekluk@gmail.com
}

(24-32 Brno)

Key words: Brno massif, Metabasite zone, Diorite zone, anisotropy of magnetic susceptibility, tectonics

\begin{abstract}
An anisotropy of magnetic susceptibility and temperature dependence on magnetic susceptibility were used to reveal an evolution history along the contact of the Metabasite and Diorite zones of Brno massif north of Brno-řečkovice. The analysis of temperature dependence of magnetic susceptibility indicated that magnetic properties of all rocks in this area are essentially controlled by magnetite with a very small contribution of pyrhotite and hematite. These minerals were formed later than the primary magmatic minerals. Therefore we assume that magnetic fabrics in studied rocks reflect deformational processes which affected these rocks. There are three patterns in anisotropy of magnetic susceptibility (AMS) in studied rocks. In the first pattern detected in diorites, the magnetic foliation is striking NE-SW, dipping to the NW and there is subvertical magnetic lineation. The second planar magnetic indicates a rotational movement of microgranite rocks along the contact of the Metabasite and Diorite zones. The last pattern found in rocks of the Metabasite zone is magnetic foliation striking NNE-SSW dipping on the NWW and magnetic lineation trending to the SW with plunge of $42^{\circ}$ and it shows normal faulting of studied area.
\end{abstract}

Úvod

Brněnský masiv je kadomský magmatický komplex na v. okraji Českého masivu. Přehled vývoje členění brněnského masivu zpracovali Hanžl a Melichar v roce 1997. Podle jejich členění jsou dva granitoidní bloky, východní a západní, rozděleny centrálním bazickým pásmem, do něhož patří dioritová a metabazitová zóna (obr. 1). Celé centrální bazické pásmo pak Leichmann a Höck (2008) považují za ofiolitový komplex. Horniny dioritové zóny jsou převážně diority, $v$ menším zastoupení serpentinizované ultrabazity a jsou lehce metamorfované. $\mathrm{V}$ metabazitové zóně jsou nejhojněji zastoupeny metabazalty s polohami metaryolitů, které jsou přeměněny ve facii zelených břidlic (Hanžl - Hrdličková 2011; Leichmann - Höck 2008). Na hranici metabazitové a dioritové zóny jsou žilná tělesa mikrogranitů s granofyrickou texturou. Tyto mikrogranity mají podobné obsahy stopových prvků jako metaryolity metabazitové zóny a mohly by tak představovat jejich subvulkanický ekvivalent (Hanžl - Hrdličková 2011). Granitoidní bloky mají stáří 580-600 Ma (van Breemen et al. 1982; Dallmeyer et al. 1994). Metaryolity $\mathrm{z}$ metabazitové zóny datoval Finger et al. (2000) na 725 Ma. Metabazitová zóna je tedy jednoznačně starší než oba granitoidní bloky. Hanžl (1997) popsal levostranné horizontální posuny v brněnském masivu s. od studované oblasti. Roupec (1992) popsal raně variské přesmyky metabazitové zóny přes devonské sedimenty na lokalitě Babí lom. Magnetickými vlastnostmi brněnského masivu se v minulosti zabýval především Hrouda (1971), Hrouda - Rejl (1973, 1974).

\section{Metodika}

Pro zjištění staveb v horninách metabazitové a dioritové zóny byla zvolena metoda anizotropie magnetické susceptibility (AMS). Tato hojně užívaná petrofyzikální metoda je založena na skutečnosti, že magnetická susceptibilita hornin má ve většině prípadů i svoji směrovou závislost vázanou na tvar zrn nebo na krystalovou strukturu nosiče magnetizace. Tyto magnetické minerály, stejně jako ostatní minerály, reagují na horninotvorné i deformační procesy a mohou tak poskytnout informace o vnitřní stavbě horniny (Tarling - Hrouda 1993). Celkově bylo změřeno 198 vzorků $\mathrm{z}$ celkem čtyř různých hornin z pěti lokalit (obr. 1,2). Orientované vzorky byly odebrány přímo z výchozů terénní vrtačkou. Měření AMS bylo provedeno v laboratořích firmy Agico, s. r. o. na př́stroji MFK1-FA. Studium magnetických vlastností hornin bylo doplněno o zjištění nosičů magnetické susceptibility u 7 vzorků. Měření těchto vzorkủ proběhla rovněž na př́istroji MFK1-FA, avšak doplněném o nemagnetickou pec CS4 od téže firmy. Závislost magnetické susceptibility na teplotě byla měřena v intervalu $20-700^{\circ} \mathrm{C}$.

Výsledkem analýzy AMS je zjištění tří vektorů, jež definují tzv. elipsoid magnetické susceptibility. Vektor K1 ukazuje směr s nejvyšší susceptibilitou, označovaný také jako magnetická lineace. Vektor K2 ukazuje směr s prostřední susceptibilitou a K3 směr s nejnižší susceptibilitou, který je normálou k magnetické foliaci. Na základě velikosti těchto zjištěných vektorů lze vypočítat stupeň anizotropie $P$ podle vzorce

$$
P=K_{1} / K_{3}
$$

Tento parametr ukazuje poměr mezi nejdelší a nejkratší poloosou elipsoidu magnetické susceptibility. 


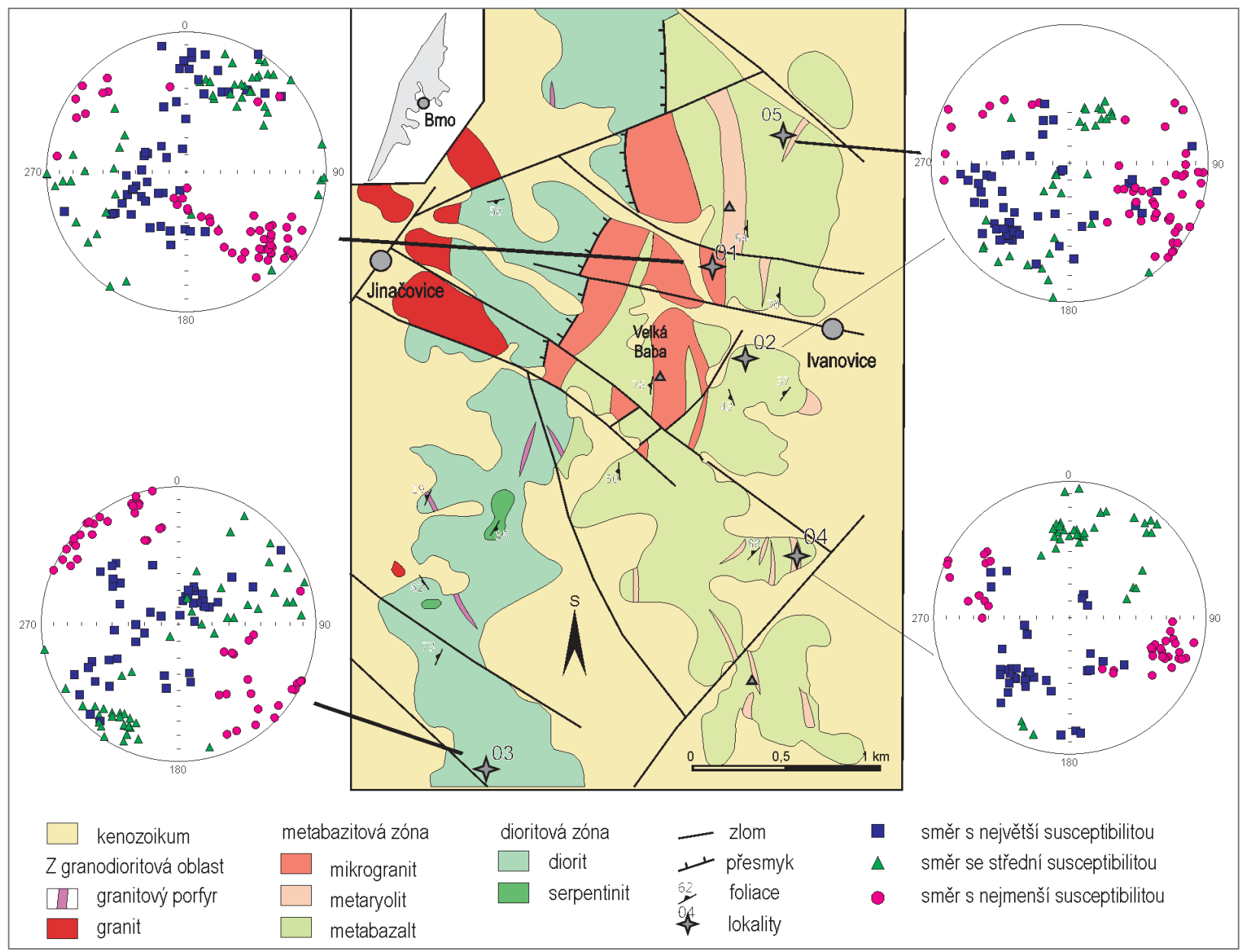

Obr. 1: Schematická mapa oblasti s AMS diagramy. AMS diagramy jsou v Lambertově projekci. Podklad podle Hanžla a Hrdličkové (2011), upraveno.

Fig. 1: Schematic map with AMS diagrams. AMS diagrams are in Lambert projection. A schematic map by Hanžl and Hrdličková (2011) was used and modified.

\section{Výsledky}

Zjištěná magnetická susceptibilita dioritů je v rozmezí $4,49 \times 10^{-4}$ až $4,57 \times 10^{-3}$ SI (obr. 2) s průměrnou susceptibilitou $1,68 \times 10^{-3} \mathrm{SI}$. Stupeň anizotropie $P$ má průměrnou hodnotu 1,06; ojediněle dosahuje až 1,25 u jednotlivých vzorků. Naměřené magnetické foliace dioritů $\mathrm{z}$ lokality 03 jsou přednostně orientovány ve směru SV-JZ s převážně velmi strmým úklonem $\mathrm{k}$ SZ i k JV. Magnetické lineace vytváří nesouvislý pás ve směru SV-JZ s lokálním maximem s orientací 45/85 (obr. 2).

AMS metabazaltů byla měřena na dvou lokalitách (02 a 05). Na základě zjištěných magnetických vlastností byly vyčleněny dva typy metabazaltů. První typ ( 47 vzorků) má magnetickou susceptibilitu v intervalu $1,41 \times 10^{-4}$ až $1,18 \times 10^{-3}$ SI s průměrnou susceptibilitou $1,69 \times 10^{-3} \mathrm{SI}$, stupeň anizotropie $P$ dosahuje 1,03 a nachází se na lokalitě 02 i 05 . Druhý typ (10 vzorků) je pouze na lokalitě 02 (lom Ivanovice) a byl vyčleněn na základě výrazně vyšší magnetické susceptibility dosahující průměrné susceptibility $8,46 \times 10^{-2}$ SI. Tyto vzorky obsahují protáhlé křemenné mandle o rozměru zhruba $1 \mathrm{~mm}$. Stupeň anizotropie $P$ u těchto vzorků dosahuje až 1,38 .

V obou typech metabazaltů lze rozpoznat stejné magnetické foliace s orientací SSV-JJZ se strmým úklo-

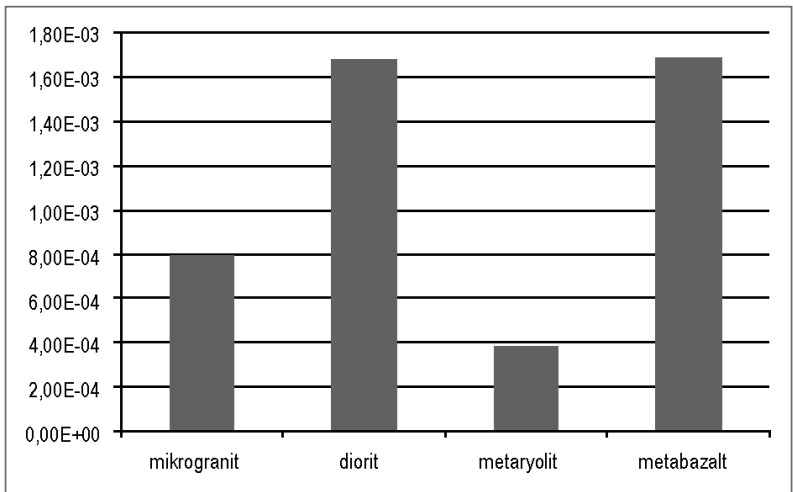

Obr. 2: Diagram s průměrnou susceptibilitou jednotlivých horninových typů. Na vertikální ose je velikost magnetické susceptibility. V diagramu nejsou zahrnuty anomální metabazalty „druhého typu“ pro zachování názornosti diagramu. Fig. 2: Average magnetic susceptibility diagram of studied rock types. Magnetic susceptibility is on vertical axis. The anomal metabasalt is not included in order to preserve clarity of the illustration.

nem k ZSZ. Magnetická lineace je rozptýlena v pásu se směrem SSV-JJZ s jedním maximem s přibližnou orientací 205/40. 
Při studiu metaryolitů byla zjištěna magnetická susceptibilita v rozmezí $1,26 \times 10^{-4}$ až $8,63 \times 10^{-4}$ SI s průměrnou susceptibilitou $3,81 \times 10^{-4} \mathrm{SI}$. Stupeň anizotropie $P$ je mezi 1,08 a 1,23. Metaryolity byly studovány na dvou lokalitách (04 a 05). Na obou byla zjištena orientace magnetické foliace ve směru SSV-JJZ strmě se uklánějící k ZSZ. Magnetické lineace na těchto lokalitách mají maximum v orientaci 205/40. Na lokalitě 05 se orientace magnetických staveb metaryolitů zcela shoduje s orientací zdejších metabazaltů.

Vzorky mikrogranitů byly odebrány na třech výchozech vzdálených od sebe asi 100 metrů (lokalita 01). Tyto výchozy jsou zjevně situovány velmi blízko tektonické hranice $s$ metabazalty. Magnetická susceptibilita je v rozmezí $9,99 \times 10^{-5}$ až $4,42 \times 10^{-3}$ SI s průměrnou susceptibilitou $7,91 \times 10^{-4}$ SI. Stupeň anizotropie $P$ dosahuje průměrné hodnoty 1,044 . V těchto horninách lze rozeznat postupnou změnu orientace ploch magnetické foliace od směru V-Z se subhorizontálním úklonem $\mathrm{k}$ S až k orientaci SV-JZ s úklonem $\mathrm{k}$ SZ. V orientaci magnetické lineace je podobný trend od orientace 11/20 k orientaci 236/57.

K určení nosiče magnetické susceptibility byly proměřeny tři vzorky mikrogranitu, tři vzorky metabazaltu a jeden vzorek metaryolitu (viz obr. 3). Podle zjištěných Curieových teplot, tedy teplot, kdy minerál přestává být feromagnetický a stává se paramagnetickým, je zřejmé, že nosičem magnetické susceptibility v téměř všech měřených vzorcích je minerál s Curieovou teplotou $575-585^{\circ} \mathrm{C}$. Nejblíže tomuto intervalu je Curieova teplota magnetitu s hodnotou $575{ }^{\circ} \mathrm{C}$. Při překročení teploty $575^{\circ} \mathrm{C}$ však zřejmě nedošlo $\mathrm{k}$ úplné přeměně feromagnetických minerálů v testovaných vzorcích, což může být způsobeno přítomností velmi malého množství jiného minerálu s vyšší Curieovou teplotou, např. hematitu nebo teplotně stálého maghemitu, který má Curieovu teplotu v rozmezí 575 až $680^{\circ} \mathrm{C}$. Přítomnost hematitu nebo oxidovaného magnetitu vzniklého částečnou martitizací magnetitu

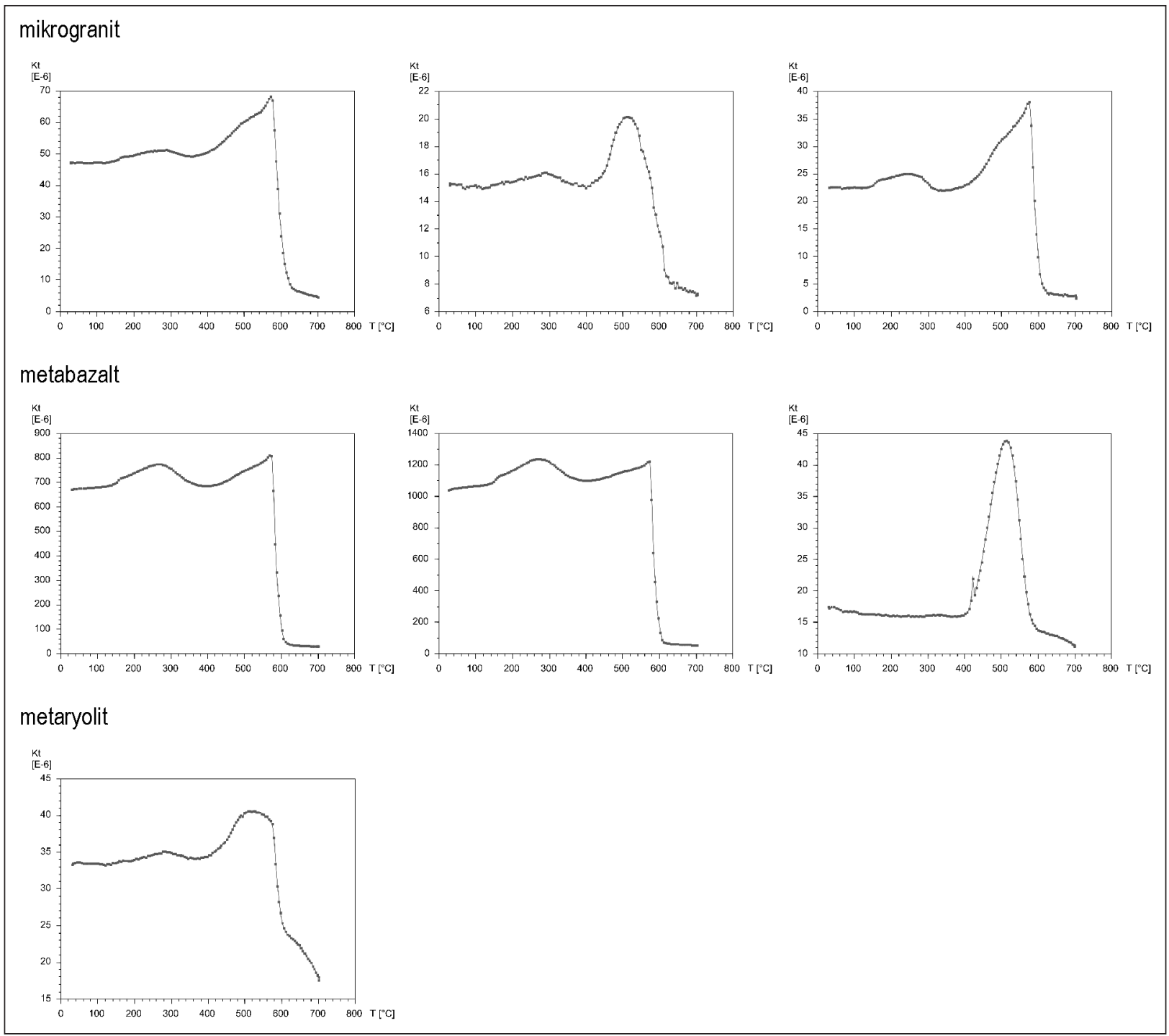

Obr. 3: Grafy závislosti magnetické susceptibility na teplotě. Na vertikální ose je velikost magnetické susceptibility a na horizontální ose je teplota.

Fig. 3: Temperature dependence of magnetic susceptibility graphs. Magnetic susceptibility is on vertical axis and temperature is on horizontal axis. 


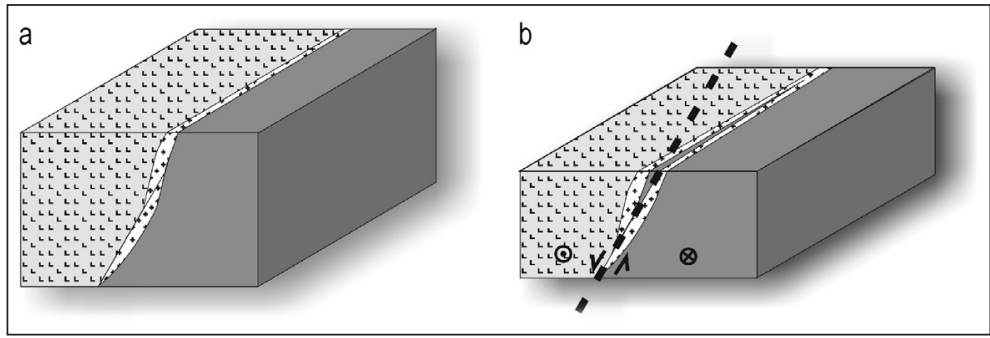

Obr. 4: Blokdiagramy znázorňující stav: a - před deformací; b - po deformaci. Fig. 4: Blockdiagrams showing the state: $\mathrm{a}$ - before deformation; $\mathrm{b}$ - after deformation.

v horninách brněnského masivu popsali Hrouda a Rejl (1973) jako výsledek metasomatických procesů. Určitá př́itomnost hematitu ve vzorcích by vysvětlovala neúplnou přeměnu vzorků při teplotě $575-585^{\circ} \mathrm{C}$. $\mathrm{U}$ všech hornin bylo na zahřívací křivce pozorováno jedno maximum kolem teploty $300{ }^{\circ} \mathrm{C}$ náležící zřejmě nízkoteplotnímu maghemitu měnínícímu se na hematit. U metabazaltů s křemennými mandlemi byl obsah tohoto minerálu znatelně vyšší, avšak vzhledem $k$ celkové susceptibilitě vzorků stále téměř zanedbatelný.

\section{Diskuze}

Rozpětí magnetické susceptibility je ve všech studovaných horninách s výjimkou „více susceptibilního metabazaltu" zhruba ve stejném rozmezí v rádech $10^{-4}$ až $10^{-3}$ SI. Avšak průměrná susceptibilita je největší u bazických hornin metabazaltů a dioritů. Nejmenší průměrná magnetická susceptibilita je u metaryolitu. Hlavním nosičem magnetické susceptibility v metabazaltech, metaryolitu a mikrogranitu je zřejmě magnetit. Z faktu, že magnetická susceptibilita dioritů je podobně vysoká jako u metabazaltů, se dá soudit, že i v dioritu bude nosičem magnetické susceptibility magnetit. Hrouda a Rejl (1973) vysvětlili vznik magnetitu $\mathrm{v}$ brněnském masivu jako výsledek metasomatických procesů. Magnetit v horninách vznikal velmi pravděpodobně ve stejné době - během metamorfních procesů spojených s deformací brněnského masivu. Magnetické vlastnosti hornin ve studované oblasti tak zřejmě odráží tyto deformační procesy.

Z hlediska reologických vlastností jsou horniny různě deformovatelné, přičemž horniny metabazitové zóny mají znaky největší deformace. Tuto úvahu lze aplikovat na zjištěné stavby AMS. Stavby metaryolitů a metabazaltů z metabazitové zóny tedy zřejmě ukazují stavby mladší, přebíjející ostatní stavby. Zřejmě mladší magnetická foliace má tedy směr SSV-JJZ s úklonem $\mathrm{k}$ ZSZ a maximum magnetické lineace má přibližnou orientaci 205/40 (obr. 1). Magnetické stavby v mikrogranitech mají v sobě zachován pás staveb, který lze interpretovat jako přechod od „stavby metabazitü“ ke „stavbě dioritü“. Konkrétně tedy plochy jejich magnetické foliace jsou natočené od přibližné orientace 315/70 po 1/15 a magnetické lineace od orientace $250 / 50$ po $2 / 15$. Magnetické foliace $v$ metabazitech by tedy mohly ukazovat plochy, podél kterých docházelo $\mathrm{k}$ levostranným horizontálním posunům brněnského masivu popsaných Hanžlem (1997) a při nichž zřejmě došlo k rotačnímu pohybu tělesa mikrogranitů. Následkem těchto procesů byly mikrogranity, tvořící původně jeden souvislý pruh, přemístěny šikmo ke směru pohybu dvou granitoidních oblastí brněnského masivu a duplikovány. Pokud byly horizontální posuny levostranné, pak magnetické lineace metabazaltů a metaryolitů ukazují, že tyto horizontální posuny měly zřejmě poklesový charakter. Poklesovou tektoniku, avšak z oblasti Kraví Hory v Brně, popsali Železný a Melichar (2002). Zdá se tak, že poklesové stř̌ižné deformace mohou mít vliv na stavbu brněnského masivu.

\section{Závěr}

Na základě studia magnetických vlastností hornin v oblasti Velké Baby u Jinačovic bylo zjištěno, že hlavním nosičem magnetické susceptibility u všech hornin je magnetit deformovaný zřejmě během jedné z deformačních fází, které postihly brněnský masiv. Při srovnání reologických a magnetických vlastností byly v těchto horninách rozpoznány orientace AMS odrážející dva deformační děje (obr. 4). První v magnetické foliaci všech hornin poukazující na levostranné horizontální posuny, druhá v magnetické lineaci metabazaltů a metaryolitů poukazující na poklesovou deformaci. Během horizontálních posunů zřejmě došlo k zešupinatění stavby metabazitové zóny v oblasti Velké Baby u Jinačovic. Tímto způsobem byl původně souvislý pruh mikrogranitů rozrušen a reorientován kose na smysl pohybu, což vysvětluje opakování pruhů mikrogranitu v metabazitové zóně.

\section{Poděkování}

Děkujeme firmě Agico, s. r. o., na jejích žpř́strojích proběhly všechny analýzy měrených vzorkủ. Recenzentüm dëkujeme za poznámky a prípomínky, které vedly ke zkvalitnění článku. 


\section{Literatura}

Breemen, O. van - Aftalion, M. - Bowes, D. R., Dudek, A. - Mísař, Z. - Povondra, P. - Vrána, S. (1982): Geochronological studies of the Bohemian massif, Czechoslovakia, and their signifi cance in the evolution of Central Europe. - Transactions of the Royal Society of Edinburgh Earth Sciences, 73, 89-108.

Dallmeyer, D. R. - Fritz, H. - Neubauer, F. - Urban, M. (1994): Ar/Ar mineralage controls on the tectonic evolution of the south-eastern Bohemian Massif. - Pre-Alpine crust i Austria, Excursion Guide, 14-22.

Finger, F. - Tichomirowa, M. - Pin, C. - Hanžl, P. (2000): Relics of an early-Panafrican metabasite-metarhyolite formation in the Brno Massif, Moravia, Czech Republic. - International Journal of Earth Sciences, 89, 328-335.

Hanžl, P. (1997): Structural profile through the Brno Massif. - Exploration Geophysics, Remote Sensing and Environment, IV: $1,29-38$.

Hanžl, P. - Melichar, R. (1997): The Brno Massif: A section through the active continental margin or a composed terrane? Krystalinikum, 23, 33-58.

Hanžl, P. - Hrdličková, K. (2011): Výskyt mikrogranitu s granofyrickou strukturou na hranici dioritové a metabazitové zóny brněnského masivu východně od Jinačovic. - Geologické výzkumy na Moravě a ve Slezsku, 2011/2, 128-133.

Hrouda, F. (1971): The magnetic fabric of some massive and mylonitized granodiorites of the most northern part of the Brno massif. - Časopis pro mineralogii a geologii, 16, 37-45.

Hrouda, F. - Rejl, L. (1973): Studium tektoniky v brněnském masivu na základě magnetických výzkumů. - Věstník Ústředního ústavu geologického, 48, 1, 1-8.

Hrouda, F. - Rejl, L. (1974): Geologická interpretace aeromagnetického mapování severní části brněnského masívu. - In: Štelcl, J. et al. (ed.): Výsledky geologického a petrologického výzkumu brněnského masívu za léta 1971-73. MS Přírodovědecká fakulta Masarykovy univerzity. Brno.

Kalvoda, J. - Bábek, O. - Fatka, O. - Leichmann, J. - Melichar, R. - Nehyba, S. - Špaček, P. (2008): Brunovistulian terrane (Bohemian Massif, Central Europe) from late Proterozoic to late Paleozoic: A review. - International Journal of Earth Sciences, 97, 3, 497-518.

Leichmann, J. - Höck, V. (2008). The Brno Batholith: An insight into the magmatic and metamorphic evolution of the Cadomian Brunovistulian unit, eastern margin of the Bohemian Massif. - Journal of Geosciences, 53, 281-305.

Roupec, P. (1992): Tektonika brněnského masivu v severním okolí Brna. - MS. Přírodovědecká fakulta Masarykovy univerzity. Brno.

Štelcl, J. - Weiss, J. (1986): Brněnský masív. - Přírodovědecká fakulta Masarykovy univerzity. Brno, 1-255.

Tarling, D. H. - Hrouda, F. (1993): The Magnetic Anisotropy of Rocks. - Champan and Hall, London.

Železný, Z. - Melichar, R. (2002): Kontakt metabazitové zóny a granitoidů brněnského masivu v Grohově ulici v Brně. - Geologické výzkumy na Moravě a ve Slezsku, 2002/1, 85-86. 